\title{
Reply to Margolis, Madelrieux and Levine
}

\section{Cheryl Misak}

\section{OpenEdition}

\section{Journals}

Electronic version

URL: http://journals.openedition.org/ejpap/553

DOl: 10.4000/ejpap.553

ISSN: 2036-4091

\section{Publisher}

Associazione Pragma

\section{Electronic reference}

Cheryl Misak, « Reply to Margolis, Madelrieux and Levine », European Journal of Pragmatism and American Philosophy [Online], V-2 | 2013, Online since 24 December 2013, connection on 21 April 2019. URL : http://journals.openedition.org/ejpap/553 ; DOI : 10.4000/ejpap.553

This text was automatically generated on 21 April 2019

\section{(c) (i) $\odot$}

Author retains copyright and grants the European Journal of Pragmatism and American Philosophy right of first publication with the work simultaneously licensed under a Creative Commons AttributionNonCommercial-NoDerivatives 4.0 International License. 


\title{
Reply to Margolis, Madelrieux and Levine
}

\author{
Cheryl Misak
}

1 Allow me to begin by thanking these three commentators for the time and energy they have put into thinking about the issues I raise in The American Pragmatists. ${ }^{1}$ There are some important common themes in their reading of the book and I am grateful for the opportunity to address them, and to clarify and expand on what I wrote.

2 One thing that common to all three readers is that they see me as offering, in Stéphane Madelrieux's words, a history of pragmatism that is both descriptive and normative - one which shows "that pragmatism has never been eclipsed from the philosophical scene even during the heyday of logical empiricism." In Steven Levine's words, I argue that "pragmatism was not simply killed off by analytical philosophy but was absorbed by it in complex ways." And Joseph Margolis has me offering both a "textualist" and a "genealogical" account of the trajectory of American pragmatism. His summary of my position is as follows:

I take Misak to be recommending that we let James swim for himself and that we concede (as we must) that Dewey never quite gets it right (philosophically) in explicating his "problematic situation" - the key to his attempt to distinguish pragmatism from untenable forms of realism and idealism; and that, accordingly, we should adopt Peirce's resolution of the pragmatist puzzle (which Dewey ultimately, though mistakenly, believes he's pretty well already adopted).

All of these descriptions of my project in The American Pragmatists seem right to me - they capture the central aim of the book nicely.

The commentators, of course, do not however agree on everything. For instance, Levine and Madelrieux think I have not been charitable to James and Margolis thinks that I have James right. Margolis, on the other hand, thinks that I have not seen the important lesson that Dewey drew for us, and Levine is more amenable to my account of Dewey.

But they do share a view about what they see as problematic in The American Pragmatists. Madelrieux objects to what he describes as my dividing up pragmatism in terms of "a 
good trend going from Charles Sanders Peirce to Clarence Irving Lewis and Wilfrid Sellars and a bad trend going from William James and John Dewey to Richard Rorty." He argues: "While it is indisputable that critics of pragmatism have focused on truth, this does not entail that truth is the best thread to understand the development of pragmatism. It is certainly not the only one." Levine has me claiming that James and Dewey thought that there is no truth and objectivity to be had anywhere and he argues that the divide between them and the more objectivist pragmatists is not nearly so neat as I would have it. Margolis thinks I "miss the essential key" in pragmatism by following Russell in making pragmatism's theory of truth and knowledge its primary feature and that I fail to appreciate how Dewey, in the end, successfully resolved the mystery of how the situation itself could be doubtful.

6 A one line summary of these worries about the general project might read as follows: Misak's focus on the issue of truth misses something important about pragmatism and, anyway, the divide she identifies and traces along the lines of truth is not such that each of the classical pragmatists fall neatly on one side or the other of it. Let me address these general worries before going on to some of the more specific arguments made by the commentators.

7 First, I fully acknowledge that my focus on truth and objectivity is but one way of approaching the tradition of pragmatism. The reason I chose this angle into the tradition is that my aim was to tell the story of the trajectory of American pragmatism: how it began, how it was received, how it evolved, and what became of it. I tried to make clear in the Preface:

The early pragmatists made major contributions to almost every branch of philosophy and to other fields of investigation-for instance, Peirce in logic and the theory of signs; James in psychology; Dewey in education. But my focus in this book will be on what Bertrand Russell calls "the cardinal point in the pragmatist philosophy" - "its theory of truth.".. It is the view of truth and knowledge that is most associated with pragmatism and marks it off from other traditions. Indeed, the reader might take this book to have an implicit subtitle: Truth, Knowledge, Value. It may be that much that is interesting in some of the pragmatists' work lies elsewhere. But the story I am tracing is the story of pragmatism as a recognizable tradition and I will leave it to others to show in a sophisticated way how, for instance, James forever changed the face of psychology. (x)

8 So there is much that I leave out of my account, especially when that material never resonated with those who were weighing in on whether pragmatism was a view that ought to be adopted or not. For instance, as Madelrieux notes, I say relatively little about action, a concept central to pragmatist thought. He is most certainly right - it would be good to expand on how the pragmatists started from the model of inquiry which has at its core the settlement of habits of belief, and moved on to how we evaluate those habits of belief in terms of whether they lead to successful action. I intend to speak to this strong current in pragmatism in my next project, which will (in part) look at how pragmatism evolved in the hands of Frank Ramsey.

But, again, the philosophical community was mostly interested in pragmatism's conception of truth, knowledge and value, and so that is the focus of my concern in the book. As I say on page 3, at the heart of my story is the fact that James was the one to unveil pragmatism to the public - in a lecture in California in 1898 - and remained its most prominent proponent. Philosophy, James said in Pragmatism, "is at once the most sublime and the most trivial of human pursuits. It works in the minutest crannies and it 
opens out the widest vistas" (3). I argue that in on his work on psychology, he worked brilliantly both in the crannies and on the vistas, but when it came to talking about truth and objectivity, he was less reliable. It was Peirce who worked on both the careful details as well as opening out the panoramic views. His version of pragmatism, however, hardly saw the light of day, much to pragmatism's misfortune.

The pragmatism that was under the spotlight was James's "The Will to Believe" and Pragmatism. Here James argues that "Any idea upon which we can ride... any idea that will carry us prosperously from any one part of our experience to any other part, linking things satisfactorily, working securely, simplifying, saving labor, is... true instrumentally." "Satisfactorily," for James, "means more satisfactorily to ourselves, and individuals will emphasize their points of satisfaction differently." James concluded that truth "is plastic" (58). Bertrand Russell, G. E. Moore, and many others savaged this account of truth. Their objections, some terribly unfair and some of them completely fair, remain at the fore today. Indeed, Peirce himself leveled some of them (the better ones) against James. When I give a talk on pragmatism in philosophy departments in the US, the UK or Europe, similar challenges are put me to time and time again. So, whatever the merits of some of James's other work, it is the James of "The Will to Believe" and Pragmatism that had a tremendous and negative effect on the fortunes of pragmatism. Part of my project is to try to reverse those fortunes.

11 The reception of Dewey was also less than positive. Again, Russell is responsible for much of the damage. I write:

Russell's main reservation is that Dewey's account of inquiry seems not to be inquiry at all. It is not a "search for truth" or for right answers, but, in Dewey's words: inquiry is the "controlled or directed transformation of an indeterminate situation into one that is so determinate in its constituent distinctions and relations as to convert the elements of the original situation into a unified whole.".. Russell notes that on this conception of inquiry, a drill sergeant who converts raw recruits into a regiment or a bricklayer who transforms a pile of bricks into a structure must be said to be successfully conducting inquiries. In inquiry, though, we are inquiring into something - we are trying to find answers to questions. We are not trying to transform one existential situation into another. (122)

I show that similar worries were articulated by Peirce and James. Russell was reacting to something that was there to be reacted against. If we are to understand where and why pragmatism is where it is today, we need to understand how the views of the classical pragmatists were received and how James left himself open to criticism on the matter of the plasticity of truth and how Dewey left himself open to criticism on the matter of making good sense of his idea of a "problematic situation." I like the way Levine puts the point: "James and Dewey (and of course Rorty) do not do justice to the fact that truth is a distinct norm of thought and inquiry that cannot be reduced to either warrantedness or to what works (in the way of thought)."

Second, I very much hope that I did not suggest that the divide I trace is perfectly straightforward. James and Dewey, for instance, intended their pragmatism to do justice to the objective dimension of human inquiry. My argument is that, despite those good intentions, more often than not, they failed to make sense of something's being objectively right or wrong. They failed to give us an account of how we might adjudicate between claims. I argue that James, in "The Moral Philosopher and the Moral Life" makes good on that promise, but that his other work is in tension with that wonderful paper. My suggestion is that Peirce is more consistent in avoiding the conclusion (or implication) 
that reality is an arbitrary construct of our own making. On Peirce's view, truth is that which would be indefeasible or would really stand up to the challenges of experience, reason and inquiry. Hence there is sense to be made of better or worse views of reality, of improving our beliefs in any domain of inquiry, and of being responsive to experience and reason.

Nonetheless, I am very much open to the arguments that, at their best, James and Dewey, like Peirce, do indeed give coherent pragmatist accounts of the human aspiration to getting things right. I think that Madelrieux is on to something important when he speaks of James's pragmatic vindication of free will (P.F. Strawson was on to the same thing, via a Kantian route). And I very much like Levine's account of how James takes us to be constrained by the world in the way that a sculptor is constrained by the block of marble he has in hand. But when Levine shows the side of James that has it that there are multiple realities and worlds, one feels the James that I described, and that Russell railed against, sneaking back onto the page.

Similarly, Margolis offers us an account of Dewey's "enlanguaged experience" or "metaphysically heuristic unity of subject and object" that sheds much light on Dewey and, especially, on Ernst Nagel's bewilderment with some of Dewey's ideas. Margolis's first-person account of Nagel's working through Dewey in his famous seminar at Columbia is fascinating and especially welcome. But again, in giving us that account, one can easily see how someone like Nagel, who was Dewey's graduate student and was wellplaced to understand him, found the more obscure Dewey re-entering the picture. While I think that Margolis is right in seeing the key to Dewey to be his excellent idea that it makes no sense to think of logic as reason-guiding if it is thought of a autonomous or pulled apart from human interest and function, I also think he is right in saying that Dewey didn't make the claim clearly enough or with enough knowledge of the logic of which he was speaking. As Margolis puts it: Perhaps Dewey had simply not earned the right to make his charge. Peirce, being a crackerjack logician, did earn the right to insist that logic was a normative science, a way of evaluating habits of reasoning. Margolis notes that this idea was picked up by other logicians. I would only add that the greatest logician who picked it up, took the idea of a logic as a normative science directly and explicitly from Peirce himself. That was Frank Ramsey. In a note to his interesting discussion here, Margolis correctly surmises that in Cambridge Pragmatism, I will speak to how philosophy cannot examine logic without viewing it as embedded in actual human practices.

16 So, despite all variations in emphasis and in substance, let me be so bold as to suggest that there is much the three readers and I agree upon and against that body of agreement, all sorts of fruitful conversations about what should be brought out in sharp relief in the pragmatist tradition can be explored.

One of those fruitful conversations will be sparked by Levine's illuminating account of James on experience. He shows how Lewis's account of thick experience is mirrored in James, especially in The Principles of Psychology. There James argues that there is far more information in the environment than we can utilize to prepare behavioral responses. We are immersed in a chaotic stream of sensory data and must select from it. And of course that selection involves bringing to that data our interests and concepts. Peirce, I would argue, puts forward a similar view. But it is embedded in his doctrine of categories, and thus is hard to extract and is less compelling than James's account. 

needs to get credit where credit is due. I shall make this correction in work that I am currently undertaking on Lewis. And I shall most certainly draw on Levine's fine exposition of it.

us far, at least on my reading, all is well and good with the interfamilial issues that occupy us, as pragmatists. But there is at least one idea that cannot, I think, be brought into the arena of constructive disagreement. Madelrieux tries to land me with a bizarre thought. He says:

the very practice of asserting and arguing presupposes that we aim to get things right so that aiming to the truth is a regulative assumption of our very practice of doing philosophy in an analytic way. In short, analytic philosophy as a mere style of philosophy presupposes the very pragmatist (and very substantial) theory of truth that she intends to promote.

If I understand him correctly, Madelrieux takes the idea that we might aspire to truth or to getting things right to somehow be part and parcel of analytic philosophy. I suspect this is, rather, Madelrieux's own view - that analytic philosophy is the kind of philosophy that upholds a substantial theory of truth. But this simply is not the case. There are plenty of analytic philosophers who argue that truth is nothing but disquotation or that truth is redundant. In fact, many of them are set against my modest account of truth because they think that it is too substantial.

21 I do in fact argue that, in the very practice of asserting or believing, we display our commitment to aiming at the truth. Madelrieux says that this argument

tends to present pragmatism's history as the divide between a kind of (good) analytic pragmatism (of which Peirce is the main forerunner) and a kind of (bad) continental pragmatism (of which Rorty is the main outcome). The divide within pragmatism would then be but the repercussion of the great divide between analytic and continental philosophy: pragmatism would only be the American way of dealing with this great divide. The conclusion is that pragmatism has brought nothing essential to philosophy, so that nothing essential would have been lost if America had not entered the philosophical scene.

This is all rather startling. For one thing, it is really not clear what we mean by "analytic philosophy." Madelrieux accuses me of having an "ambiguous definition" of analytic philosophy. But on the first page, I think I am clear that there is very little sense these days to attempt any definition of this concept or method:

"Analytic philosophy" used to have a clear meaning when in the hands of the likes of Bertrand Russell: "logical analysis" was the attempt to clarify a concept by using formal methods to reduce it to its constituent parts. It might have been the case that for some years in the mid to late 1900s, pragmatists had reason to distinguish themselves from that kind of analysis and from a kind of finely wrought philosophy which they took to be irrelevant to the problems we actually face in the world. But logical analysis has come and gone as a way of doing philosophy. Perhaps "analytic philosophy" now suggests to some that the philosophy of language is the foundation of philosophy; perhaps that logic is the foundation of philosophy. But it is more realistic to think that the term has lost any precise meaning it once had (1).

Or, as I put in later in the book, Sellars rightly objected to the idea that the task of the philosopher is "analysis in the sense of definition - the task, so to speak, of "making little ones out of big ones'." This "atomistic philosophy," Sellars says, "is a snare and a delusion" (221). But once we say that about analytic philosophy, there is not much else we 
can say. Madelrieux needs to tell us why on earth we would accept such a particular and burdened account of it as the one he suggests.

So let me end by setting the record straight. I do not think that it is helpful to view the interfamilial disputes that have been part of pragmatism since its inception through the lens of the analytic-continental distinction. Part of my aim in The American Pragmatists was to show that, as I put it on (226): "The very categories of analytic versus Continental philosophy, over the last decades, have been disintegrating." But if others, including Madelrieux, want to approach the matter from that perspective, then it is of course open to them to produce alternative accounts of the history and trajectory of pragmatism. But in doing so, they should, I think, take account of the engagements between the pragmatists and those so-called analytic enemies of pragmatism - Russell, the logical empiricists, Quine, Davidson, and so on. I suspect that they too will feel the categories shifting and sliding until there is very little left of them.

\section{NOTES}

1. Oxford, Oxford University Press, 2013. All references in the text will be to this work.

\section{AUTHOR}

CHERYL MISAK

University of Toronto

cheryl.misak[at]utoronto.ca 